\title{
Increased adipose tissue PC-1 protein content, but not tumour necrosis factor- $\alpha$ gene expression, is associated with a reduction of both whole body insulin sensitivity and insulin receptor tyrosine-kinase activity
}

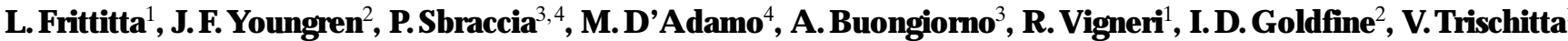 \\ ${ }^{1}$ Istituto di Medicina Interna e Malattie Endocrine e Metaboliche, Università di Catania-Ospedale Garibaldi, Catania, Italy \\ ${ }^{2}$ Diabetes Research Laboratory, Mount Zion Hospital, University of San Francisco, California, USA \\ ${ }^{3}$ Clinical Biochemistry Laboratory, Istituto Superiore di Sanità, Rome, Italy \\ ${ }^{4}$ Division of Endocrinology 1, University "La Sapienza", Rome, Italy
}

Summary In the present study we measured PC-1 content, tumour necrosis factor (TNF)- $\alpha$ gene expression, and insulin stimulation of insulin receptor tyrosine-kinase activity in adipose tissue from nonobese, non-diabetic subjects. These parameters were correlated with in vivo insulin action as measured by the intravenous insulin tolerance test ( $\mathrm{K}_{\mathrm{itt}}$ values). PC-1 content was negatively correlated with $\mathrm{K}_{\mathrm{itt}}$ values $(r=-0.5, p=0.04)$ and positively with plasma insulin levels both fasting $(r=0.58, p=0.009)$ and after 120 min during oral glucose tolerance test (OGTT) $(r=0.67, p=0.002)$. Moreover, adipose tissue PC-1 content was higher in relatively insulin-resistant subjects $\left(\mathrm{K}_{\mathrm{itt}}\right.$ values lower than 6) than in relatively insulin-sensitive subjects ( $K_{\text {itt }}$ values higher than 6) $(525 \pm 49 \mathrm{ng} / \mathrm{mg}$ protein vs $336 \pm 45$, respectively, $\mathrm{p}=0.012$ ). Adipose tissue insulin receptor tyrosinekinase activity in response to insulin was significantly lower at all insulin concentrations tested $(p=0.017$, by two-way analysis of variance test) in insulin-resistant than in insulin-sensitive subjects $\left(\mathrm{K}_{\mathrm{itt}}\right.$ values lower or higher than 6 , respectively). In contrast to PC-1, no significant correlation was observed between adipose tissue TNF- $\alpha$ mRNA content and $K_{\text {itt }}$ values, and plasma insulin levels, both fasting and at after 120 min during OGTT. Also, no difference was observed in TNF- $\alpha$ mRNA content between subjects with $K_{\text {itt }}$ values higher or lower than 6 . These studies in adipose tissue, together with our previous studies in skeletal muscle raise the possibility that PC-1, by regulating insulin receptor function, may play a role in the degree of insulin sensitivity in non-obese, nondiabetic subjects. [Diabetologia (1997) 40: 282-289]

Keywords Adipose tissue, insulin sensitivity, insulin tolerance test, insulin receptor tyrosine-kinase inhibitors, tumour necrosis factor- $\alpha$, PC- 1 .
The pathophysiology of non-insulin-dependent diabetes mellitus (NIDDM) is complex, consisting of both abnormal insulin secretory patterns, and resistance to the actions of insulin [1-8]. While insulin resistance is a characteristic feature of many NIDDM patients, it is also observed in non-diabetic subjects [1]. In fact, it has been estimated that up to $25 \%$ of

Received: 2 August 1996 and in revised form: 16 October 1996

Corresponding author: Dr. V. Trischitta, Endocrinologia-Ospedale Garibaldi, Piazza S. M. Gesù, I-95123 Catania - Italy A bbreviations: NIDDM, Non-insulin-dependent diabetes mellitus; OGTT, oral glucose tolerance test; ITT, insulin tolerance test; PMSF, phenylmethylsulphonylfluoride; RT-PCR, reverse transcriptase polymerase chain reaction. normoglycaemic non-obese individuals are as insulin resistant as NIDDM patients [1], and it has been suggested that a significant proportion of these individuals will eventually develop diabetes if either insulin secretion declines and/or insulin resistance increases [1]. However, in most individuals, the cellular mechanisms causing human insulin resistance are not understood [3-8].

Insulin regulates cellular functions by binding to the insulin receptor, a tetrameric plasma membrane glycoprotein of the receptor tyrosine-kinase family [6-8]. After binding, insulin activates receptor tyrosine-kinase activity, leading to the phosphorylation of key intracellular substrates, and insulin action ensues [6-8]. Many studies have been performed on insulin receptor tyrosine-kinase activity in NIDDM 
patients [9-18] and most [9-14, 16-18] have reported that in these patients receptor function is reduced in muscle and adipose tissues, the major insulin target tissues. Moreover, in healthy non-obese, non-diabetic subjects in vivo insulin sensitivity also correlates with in vitro insulin stimulation of insulin receptor tyrosine-kinase activity in both skeletal muscle and adipose tissue [19]. Finally, a decreased insulin receptor tyrosine-kinase activity has also been reported in skeletal muscle of non-diabetic, insulin-resistant subjects who are first-degree relatives of NIDDM patients [20]. These data suggest, therefore, that insulin receptor tyrosine-kinase activity plays a major role in the regulation of insulin sensitivity in both non-diabetic and diabetic subjects. In most instances, however, the factors that regulate insulin receptor function are unknown.

Recently several potential specific inhibitors of insulin receptor tyrosine-kinase activity have been described in insulin-resistant humans [21-24]. These inhibitors include membrane glycoprotein PC-1 [21], a protein expressed in many tissues, and cytokine tumour necrosis factor- $\alpha$ (TNF- $\alpha$ ) [22], a secretory protein produced primarily in adipose tissue.

We have observed that PC-1 content is elevated in dermal fibroblasts of NIDDM patients [21]. Others have found that PC-1 activity is elevated in fibroblasts from patients with severe, post-receptor insulin resistance [25]. We have previously demonstrated that in obesity, skeletal muscle PC-1 expression inversely correlates with insulin sensitivity [26], and also that an increased PC-1 content in skeletal muscle tissue of healthy non-obese subjects is associated with both a reduced insulin action in vivo and diminished insulin receptor tyrosine-kinase activity in vitro [27]. These studies suggest, therefore, that PC-1 overexpression may play a role in human insulin resistance by regulating insulin receptor function in skeletal muscle tissue, the major target tissue for insulin-stimulated glucose disposal [2]. However, no data are available on the relationship between whole body insulin sensitivity and PC-1 content in human adipose tissue, a tissue that, although it accounts for only a small fraction of insulin-stimulated glucose disposal [28], plays a fundamental role in insulin resistance by regulating non-esterified free fatty acid levels $[29,30]$.

In obese, insulin-resistant rodents TNF- $\alpha$ gene expression is elevated in adipose tissue and plays a role in altering insulin receptor tyrosine-kinase activity [31]. Also in obese patients with or without NIDDM, TNF- $\alpha$ has been reported to be overexpressed in adipose tissue [32, 33] and also in skeletal muscle [34]. The role of TNF- $\alpha$ in insulin resistance have been assessed, therefore, in obese and/or NIDDM patients [32-34]; it is unknown, however, whether adipose tissue TNF- $\alpha$ overexpression also plays a role in human insulin resistance not associated with either obesity and/or NIDDM.
In the present study we have obtained adipose tissue from non-obese, non-diabetic individuals with a wide range of insulin sensitivity. In this tissue, PC-1 protein content, TNF- $\alpha$ gene expression, and insulin receptor tyrosine-kinase activity were measured in order to understand the relationship between these two inhibitors of insulin receptor tyrosine-kinase activity in adipose tissue and whole body insulin sensitivity, in the absence of any interference due to obesity and/or NIDDM.

\section{Subjects, materials and methods}

Crystalline porcine insulin, Triton X-100, Bacitracin, p-methyl sulphonylfluoride (PMSF) and poly Glu-Tyr (4:1) were purchased from Sigma Chemical Co. (London, UK). ${ }^{125} \mathrm{I}_{-} \mathrm{A}_{14}$-insulin (340-360 mCi/mg) was kindly provided by Dr. L. Benzi (Pisa, Italy). (gamma ${ }^{32} \mathrm{P}$ ) ATP was obtained from Amersham Ltd (London, UK).

Subjects. Twenty (13 males and 7 females) healthy non-obese subjects undergoing elective abdominal surgery were studied after giving informed consent, in accordance with the declaration of Helsinki. All subjects were fed a weight-maintaining diet ( $50 \%$ carbohydrate, $30 \%$ lipid, and $20 \%$ protein) for the 8 days preceding the study. According to World Health Organization criteria, they were not diabetic as evaluated by oral glucose tolerance test (OGTT). After an overnight fast, insulin sensitivity was assessed in these subjects by intravenous (i.v.) insulin tolerance test (ITT), performed by injecting regular insulin (0.1 IU per kg of body weight), as a single bolus [19, 27, 35]. Blood samples were collected 15 and 5 min before and 3 , $6,9,12$, and 15 min after insulin injection. Glucose was injected at $15 \mathrm{~min}$ to stop the fall in blood glucose. The constant rate for plasma glucose disappearance $\left(\mathrm{K}_{\mathrm{itt}}\right)$ was calculated according to the formula $0.693 / t 1 / 2$. The plasma glucose $t 1 / 2$ was calculated from the slope of least square analysis of the plasma concentration declined linearly. The results obtained with this test correlate highly with those obtained in euglycaemic hyperinsulinaemic clamp studies, and are not influenced by counterregulatory hormones in the 3-15 min period of the study [35]. In order to verify the reproducibility of $K_{\text {itt }}$ values, a second ITT was carried out in four subjects within 3 weeks from the first test. In all four cases the $\mathrm{K}_{\mathrm{itt}}$ value obtained with the second test was within $8 \%$ of the value obtained at the first (data not shown).

Tissue specimens. Abdominal subcutaneous adipose tissue was obtained at elective abdominal surgery (cholecystectomy) 35 days after ITT and OGTT, and immediately frozen in liquid nitrogen.

\section{P C -1 and insulin receptor content}

Tissue preparation. Adipocyte membranes were prepared from frozen tissue biopsies. Approximately $200 \mathrm{mg}$ frozen adipose tissue was pulverized under liquid nitrogen. The resultant powder was homogenized in $2.5 \mathrm{ml}$ membrane buffer $(50 \mathrm{mmol} / \mathrm{l}$ HEPES, $225 \mathrm{mmol} / \mathrm{l}$ Sucrose, $150 \mathrm{mmol} / \mathrm{l} \mathrm{NaCl}, 1 \mathrm{mmol} / \mathrm{l}$ PMSF, $2 \mu \mathrm{mol} / 1$ leupeptin, $2 \mu \mathrm{mol} / 1$ pepstatin A, pH 7.6) at $4{ }^{\circ} \mathrm{C}$ using a polytron homogenizer (Kinematica, Lucerne, Switzerland) for $10 \mathrm{~s}$ at a setting of 6 . The homogenate was centrifuged at $1000 \mathrm{~g}$ for $30 \mathrm{~min}$ at $4{ }^{\circ} \mathrm{C}$. The fat cake was 
removed and the infranatant was collected and centrifuged at $100000 \mathrm{~g}$ for $60 \mathrm{~min}$ at $4^{\circ} \mathrm{C}$. The supernatant was discarded and the membrane pellet re-suspended in $300 \mu$ l solubilization buffer $(50 \mathrm{mmol} / 1 \mathrm{HEPES}, 150 \mathrm{mmol} / \mathrm{l} \mathrm{NaCl}, 1 \mathrm{mmol} / \mathrm{l} \mathrm{PMSF}$, $2 \mu \mathrm{mol} / 1$ leupeptin, $2 \mu \mathrm{mol} / 1$ pepstatin A, $1 \%$ Triton $\mathrm{X}-100$, $\mathrm{pH}$ 7.6). The membranes were then spun in a microfuge for $30 \mathrm{~min}$ at $4^{\circ} \mathrm{C}$, the supernatants collected and stored at $-70^{\circ} \mathrm{C}$. Protein content of the solubilized membrane preparations were determined by the Bradford method [36].

\section{Insulin receptor and PC-1 E L ISA}

The insulin receptor and PC-1 content in adipose membranes (which contain more than $95 \%$ of total tissue content for both proteins) was determined by running specific ELISAs for each of the two proteins. Biotinylation of secondary antibodies used in both assays was performed as previously described [37].

In the insulin receptor ELISA, microtitre 96 plates were coated with $0.2 \mu \mathrm{g}$ anti-insulin receptor antibody MA-20 in $100 \mu \mathrm{l} 50 \mathrm{mmol} / \mathrm{l} \mathrm{Na} \mathrm{CO}_{3}, \mathrm{pH}$ 9.0. After an 18-h incubation at $4^{\circ} \mathrm{C}$, the wells were washed three times with TBST buffer ( $20 \mathrm{mmol} / \mathrm{l}$ Tris, $150 \mathrm{mmol} / \mathrm{l} \mathrm{NaCl}, 0.05 \%$ TWEEN-20) to remove unbound antibody. Next the wells were blocked with $150 \mu \mathrm{l}$ TBST containing $1 \%$ bovine serum albumin (BSA) for $30 \mathrm{~min}$ at $56^{\circ} \mathrm{C}$. The wells were then washed three times with TBST. Solubilized adipose membranes were diluted to a concentration of $200 \mu \mathrm{g}$ protein/ $\mathrm{ml}$ with binding buffer $(50 \mathrm{mmol} /$ 1 HEPES, $150 \mathrm{mmol} / 1 \mathrm{NaCl}, 0.1 \%$ bovine serum albumin (BSA), $0.1 \%$ Triton X-100, $1 \mathrm{mmol} / \mathrm{l} \mathrm{PMSF}, 1 \mathrm{mg} / \mathrm{ml}$ bacitracin, $2 \mu \mathrm{mol} / \mathrm{l}$ leupeptin, and $2 \mu \mathrm{mol} / \mathrm{l}$ pepstatin, $\mathrm{pH} 7.6$ ), and $100 \mu \mathrm{l}(20 \mu \mathrm{g}$ protein) was added to each well. Additionally, multiple dilutions of an insulin receptor standard (0-2.0 ng insulin receptor) were loaded onto each plate as a standard curve. Receptors were allowed to bind overnight at $4{ }^{\circ} \mathrm{C}$. The wells were then washed five times with TBST before adding a 1:2000 dilution of the biotinylated anti-insulin receptor antibody 29B4 in $100 \mu \mathrm{l}$ buffer B (50 mmol/l HEPES, $150 \mathrm{mmol} / \mathrm{l}$ $\mathrm{NaCl}, 0.05 \%$ TWEEN-20, 2 mmol $/ 1 \mathrm{Na}_{3} \mathrm{VO}_{4}, 1 \mathrm{mg} / \mathrm{ml}$ bacitracin, $1 \mathrm{mmol} / \mathrm{l} \mathrm{PMSF}, 1 \% \mathrm{BSA}, \mathrm{pH} 7.6)$. Incubation with the antibody continued for $2 \mathrm{~h}$ at $22^{\circ} \mathrm{C}$. Wells were again washed five times with TBST, and $10 \mathrm{ng}$ peroxidase-conjugated streptavidin was added in $100 \mu \mathrm{l}$ buffer B. Following a 30-min incubation at $22^{\circ} \mathrm{C}$, wells were washed five times with TBST and $100 \mu \mathrm{l}$ of biotinyl-tyramide solution was added for a 15 -min incubation at $22^{\circ} \mathrm{C}$. Wells were then washed five times with TBST and $100 \mu \mathrm{l}$ phosphate buffered saline-T (in mmol/l: 137 $\mathrm{NaCl}, 8 \mathrm{Na}_{2} \mathrm{HPO}_{4}, 2.7 \mathrm{KCl}, 1.15 \mathrm{KH}_{2} \mathrm{PO}_{4}, 1 \%$ BSA, $0.05 \%$ TWEEN-20) containing $0.2 \mu \mathrm{l}$ streptavidin-horseradish peroxidase solution was added for a 30 -min incubation at $22^{\circ} \mathrm{C}$. After washing five times with TBST, $100 \mu \mathrm{l} 3,3^{\prime}, 5,5^{\prime}$ tetramethylbenzidine peroxidase substrate was added. Colour development proceeded for $8 \mathrm{~min}$ at $2{ }^{\circ} \mathrm{C}$, and was then stopped by the addition of $100 \mu \mathrm{l} 1 \mathrm{~mol} / 1 \mathrm{H}_{3} \mathrm{PO}_{4}$. The absorption at $450 \mathrm{~nm}$ of each well was measured in a microtitre plate reader. The assay was able to accurately quantify below $100 \mathrm{pg}$ insulin receptor utilizing the linear portion of the standard curve.

The PC-1 ELISA was carried in an identical manner with the following exception: the 96-well plates were pre-coated with an antibody to the membrane glycoprotein PC-1 $(0.2 \mu \mathrm{g}$ anti-PC-1 polyclonal antibody [38] in $100 \mu \mathrm{l} 50 \mathrm{mmol} / \mathrm{l}$ $\mathrm{Na}_{2} \mathrm{CO}_{3}, \mathrm{pH} 9.0$, generously provided by Dr. I. Yamashina), $2.0 \mu \mathrm{g}$ protein was added to each well, the standard curve was constructed by multiple dilutions of $0-1.5 \mathrm{ng}$ purified $\mathrm{PC}-1$, and the second antibody used was a biotinylated anti-PC-1 monoclonal antibody made by immunizing mice with native
PC-1 protein. The assay was able to accurately quantify below $50 \mathrm{pg}$ PC-1 utilizing the linear portion of the standard curve.

\section{TNF- $\alpha$ gene expression}

RNA preparation. Abdominal subcutaneous adipose tissue specimens (100 mg) were pulverized in liquid nitrogen. Total RNA was isolated using Ultraspec RNA Isolation System (Biotecx Laboratories Inc., Houston, Texas, USA) according to the manufacturer's protocol. Quantity and purity of RNA were determined by absorbance at 260 and $280 \mathrm{~nm}$. Quality of RNA was verified by ethidium bromide staining of ribosomal RNA bands on a $1 \%$ agarose minigel.

Quantitative reverse transcriptase polymerase chain reaction (RT-PCR). Quantitative competitive RT-PCR was performed according to previously described techniques [39-41]. One hundred ng of total RNA was mixed with decreasing quantities, using serial 1:2 dilutions (from $4 \times 10^{3}$ to $1.25 \times 10^{2}$ molecules), of a complementary RNA (cRNA) construct (Gene Amplimer PAW 109 RNA, Perkin-Elmer, Norwalk, Conn., USA) containing primer sites for human TNF- $\alpha$. These primer sites were located at nucleotides $330-350$ and $635-655$ of the human TNF- $\alpha$ cDNA [42]. Because the primers span an intron in the TNF- $\alpha$ gene [43], contamination with genomic DNA during the PCR reaction is avoided. PCR with this cRNA generates a product that is 24 nucleotides shorter than the PCR product generated from native human TNF- $\alpha$ messenger RNA (mRNA). First strand cDNA synthesis was performed using Moloney murine leukemia virus reverse transcriptase (GIBCO-BRL, Gaithersburg, Md., USA) and random hexamer primers (Pharmacia, Uppsala, Sweden) in a total volume of $20 \mu \mathrm{l}$ of (in $\mathrm{mmol} / \mathrm{l}$ ): $50 \mathrm{KCl}, 10$ Tris- $\mathrm{HCl} \mathrm{pH} \mathrm{8.3,5} \mathrm{MgCl,} \mathrm{dNTPs} \mathrm{(Pharmacia).} \mathrm{After}$ a 45 -min incubation at $42^{\circ} \mathrm{C}$, the entire $20 \mu \mathrm{l} \mathrm{cDNA}$ synthesis reaction volume was combined in a $100-\mu$ l final reaction volume for PCR amplification containing $0.15 \mathrm{mmol} / \mathrm{l}$ of primers and 2.5 U Taq DNA polymerase (AmpliTaq, Perkin-Elmer). PCR amplification was carried out for 35 cycles of $15 \mathrm{~s}$ at $95^{\circ} \mathrm{C}$, and $30 \mathrm{~s}$ at $60^{\circ} \mathrm{C}$, followed by a final step of $7 \mathrm{~min}$ at $72^{\circ} \mathrm{C}$, using a GeneAmp PCR System 2400 (Perkin-Elmer). Products of PCR amplification were resolved by electrophoresis on $20 \%$ polyacrilamide gels. Gels were silver stained and band density quantified by laser scanning densitometry (Hoefer, San Francisco, Calif., USA). The ratio of cRNA standard/TNF- $\alpha$ product was plotted against the number of copies of cRNA added, to yield the equivalence point between cRNA and TNF- $\alpha$ mRNA. Intra- and inter-assay coefficient of variation of PCR products quantified as described above were 2.4 and $4.5 \%$, respectively. A representative experiment is shown in Figure 1.

\section{Insulin receptor tyrosine-kinase activity}

Tissue preparation. Adipose tissue (approximately $300 \mathrm{mg}$ ) was powdered in the presence of liquid nitrogen and then homogenized at $4{ }^{\circ} \mathrm{C}$ by a Polytron homogenizer $(20 \mathrm{~s}$ at medium speed) in $50 \mathrm{mmol} / 1$ HEPES buffer $\mathrm{pH} \mathrm{7.6,} \mathrm{containing} \mathrm{(in}$ mmol/l) $150 \mathrm{NaCl}, 5$ EDTA, 5 EGTA, 20 sodium pyrophosphate, $1 \mathrm{PMSF}, 1$ sodium-vanadate, 20 sodium fluoride, $1 \mathrm{mg} /$ $\mathrm{ml}$ bacitracin. The homogenized material was centrifuged at $200 \times \mathrm{g}$ for $2 \mathrm{~min}$ in order to remove the fat cake and then solubilized by adding $1 \%$ Triton X-100 (final concentration) and maintained under continuous shaking for $1 \mathrm{~h}$ at $4{ }^{\circ} \mathrm{C}$. Solubilized material was then centrifuged at $100000 \mathrm{~g}$ and the supernatant used for the tyrosine-kinase activity measurement. 

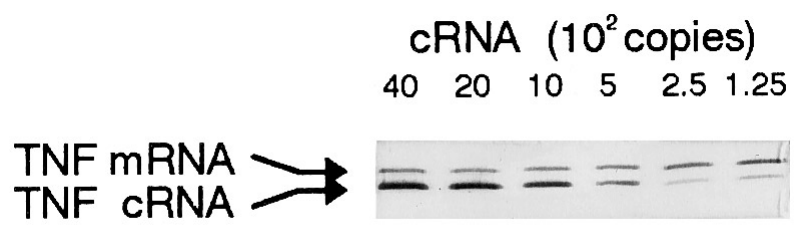

A

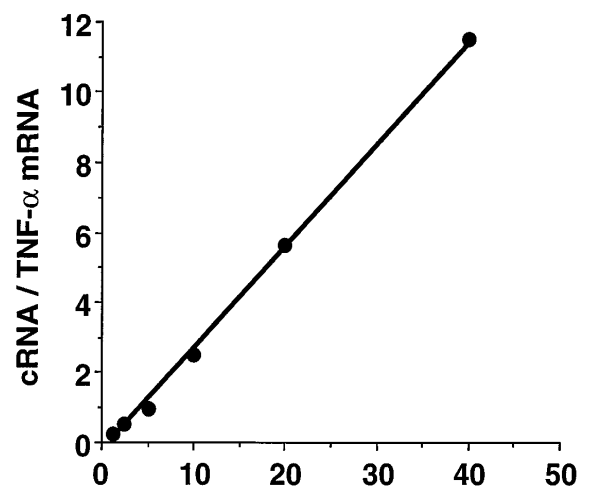

B

cRNA copies $\left(10^{2}\right)$

Fig. 1. (A, B ) Quantification of adipose tissue TNF- $\alpha$ mRNA levels by reverse transcriptase-polymerase chain reaction (RT-PCR). A . Silver nitrate staining of the PCR products separated by PAGE. Total RNA (100 ng) was added to the indicated increasing quantities of cRNA construct containing primer sites for human TNF- $\alpha$. The amplification product of this cRNA contruct, which is 24 nucleotides shorter than cDNA amplified from human TNF- $\alpha$ mRNA, corresponds to the lower band of the gel. B. The density ratio of the two bands shown in panel A was plotted against the number of copies of cRNA. The linear regression analysis is performed on the line and the equivalence point determined. Data are expressed as the number of copies/100 ng of total RNA

Tyrosine-kinase phosphorylation of the exogenous substrate poly-glu $4: 1$. Tyrosine-kinase activity of insulin receptor was assessed by a modification $[19,27,44]$ of the previously described procedure [45]. In order to minimize the influence of day-today variation of tissue solubilization and receptor immunopurification, we always studied in parallel in the same day specimens from two subjects with either high $\left(\mathrm{K}_{\mathrm{itt}}\right.$ value greater than 6$)$ or low $\left(\mathrm{K}_{\mathrm{itt}}\right.$ value less than 6$)$ in vivo insulin sensitivity.

\section{Statistical analysis}

Unpaired Student's t-test was utilized to compare mean values. Two-way analysis of variance (ANOVA test) was utilized to compare insulin dose-response curves.

Linear regression analysis (if the data were distributed normally) or Spearman correlation analysis (if the data were not distributed normally) were utilized to look for numerical correlation between variables. Data are expressed as mean \pm SEM.

\section{Results}

In vivo sensitivity to insulin. Clinical features of the 20 subjects studied are shown in Table 1. Insulin sensitivity, as assessed by ITT ( $\mathrm{K}_{\text {itt }}$ values), ranged between 2.9 and 8.1 with a median value of 6.0 and a mean value $\pm S E M$ of $5.6 \pm 0.3$. These data confirm our previous observations that insulin sensitivity varies widely in non-obese normoglycaemic subjects $[19,27]$. In concert with our previous observations $[19,27]$, a significant negative correlation was observed between $K_{\text {itt }}$ values and both plasma insulin and glucose levels at 120 min during OGTT ( $r=$ $-0.45, p=0.048$, and $r=-54, p=0.014$, respectively) (Fig. 2) and also between $K_{\text {itt }}$ values and fasting plasma glucose levels $(r=-0.53, p=0.015)$.

PC-1 content and relationship to insulin sensitivity. PC-1 content was measured in adipose tissue specimens of 19 non-obese, non-diabetic subjects and ranged from 67 to $855 \mathrm{ng} / \mathrm{mg}$ protein with a median value of 392 and a mean value \pm SEM of $436 \pm 39$.

In these subjects increasing adipose tissue PC-1 content was associated with decreasing in vivo insulin sensitivity. PC-1 content negatively and significantly correlated with $K_{i t t}$ values $(r=-0.57, p=0.011)$ (Fig. 3). PC-1 content also significantly correlated with plasma insulin levels both fasting $(r=0.58$, $p=0.009)$ and $120 \mathrm{~min}$ during OGTT $(r=0.67$, $p=0.002$ ). In contrast, no significant correlation was observed between PC-1 content and either fasting plasma glucose levels or BMI (data not shown).

The subjects were then subdivided into those who were relatively insulin sensitive $\left(\mathrm{K}_{\mathrm{itt}}\right.$ values greater than 6 which is the median $\mathrm{K}_{\mathrm{itt}}$ value when both the 20 non-obese, non-diabetic subjects studied in the present paper and a larger series of 44 non-obese, non-diabetic subjects studied in our laboratory, are considered) and those who were relatively insulin resistant $\left(\mathrm{K}_{\mathrm{itt}}\right.$ values less than 6$)$. The insulin-resistant subjects $(n=10)$ had a significantly higher PC-1 content as compared to the insulin-sensitive subjects $(n=9)(525 \pm 49$ vs $336 \pm 45, p=0.012)$ (Fig. 4).

TNF- $\alpha$ gene expression and relationship to insulin sensitivity. The abundance of the specific TNF- $\alpha$

Table 1. Clinical features of the 20 subjects studied

\begin{tabular}{lllll}
\hline & $\begin{array}{l}\text { Age } \\
(\text { years })\end{array}$ & $\begin{array}{l}\text { Body mass index } \\
\left(\mathrm{kg} / \mathrm{m}^{2}\right)\end{array}$ & $\begin{array}{l}\text { Fasting plasma glucose } \\
(\mathrm{mmol} / \mathrm{l})\end{array}$ & $\begin{array}{l}\text { Fasting plasma immunoreactive insulin } \\
(\mathrm{pmol} / \mathrm{l})\end{array}$ \\
\hline Mean \pm SEM & $33 \pm 3$ & $24 \pm 1$ & $5.0 \pm 0.1$ & $86 \pm 9$ \\
Range & $15-64$ & $21-27$ & $4.3-6.5$ & $20-166$ \\
\hline
\end{tabular}




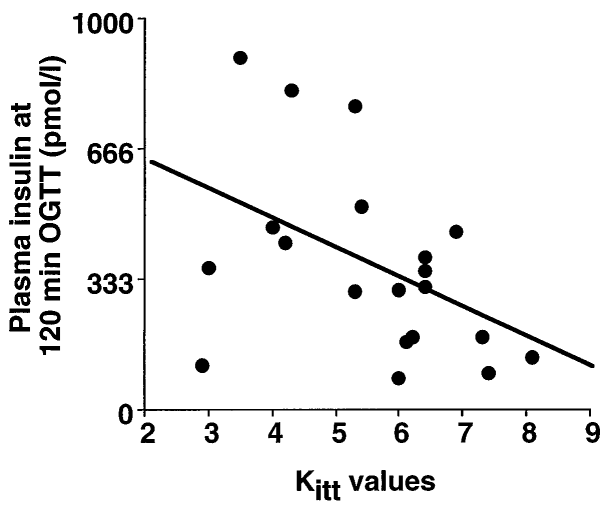

A

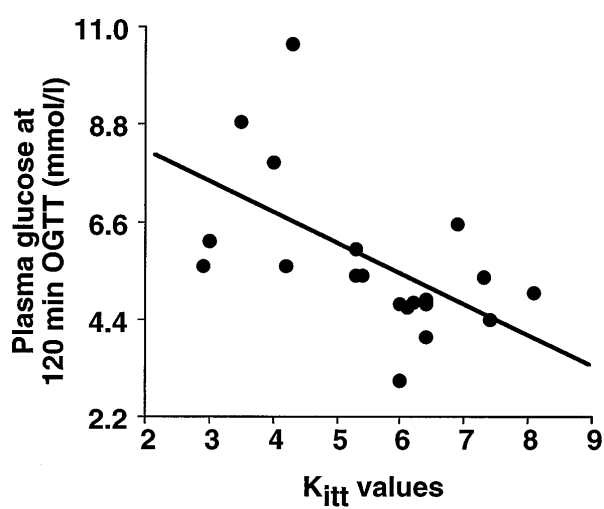

B

Fig. 2. (A , B ) Correlation between whole body insulin sensitivity (as indicated by $\mathbf{K}_{\text {itt }}$ values) and insulin (A) and plasma glucose (B) levels at 120 min during OGTT, in non-obese, non-diabetic subjects

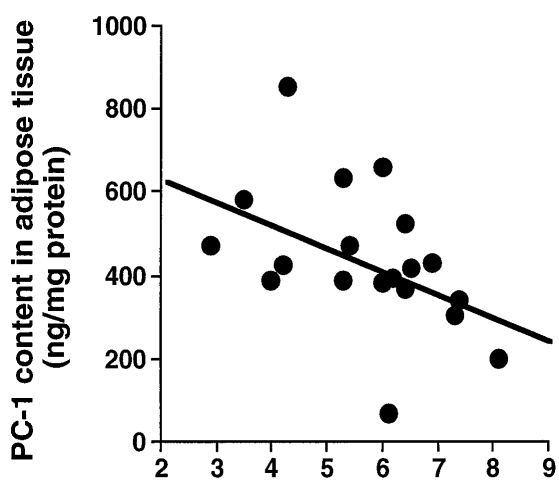

$K_{\text {itt }}$ values

Fig. 3. Correlation between PC-1 content in adipose tissue of non-obese, non-diabetic subjects and in vivo insulin sensitivity, as indicated by $\mathrm{K}_{\mathrm{itt}}$ values

mRNA, relative to an internal cRNA standard, was measured in 17 subjects using the quantitative RTPCR technique. The cRNA/mRNA equivalence point was taken as the quantity of TNF- $\alpha$ mRNA present and expressed as the number of copies per $100 \mathrm{ng}$ total RNA. It ranged from 80 to 4350 copies/ $100 \mathrm{ng}$ RNA with a median value of 554 and a mean \pm SEM of $866 \pm 247$. In contrast to PC- 1 , no significant correlation was observed between TNF- $\alpha$

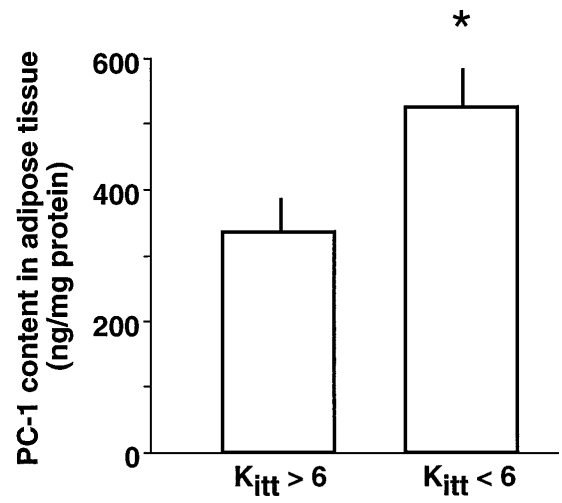

Fig. 4. PC-1 content in adipose tissue of nine relatively insulinsensitive subjects $\left(\mathrm{K}_{\mathrm{itt}}>6\right)$ and ten relatively insulin-resistant subjects $\left(K_{\text {itt }}<6\right)$. Data are expressed as mean $\pm S E M$ $* p=0.012$

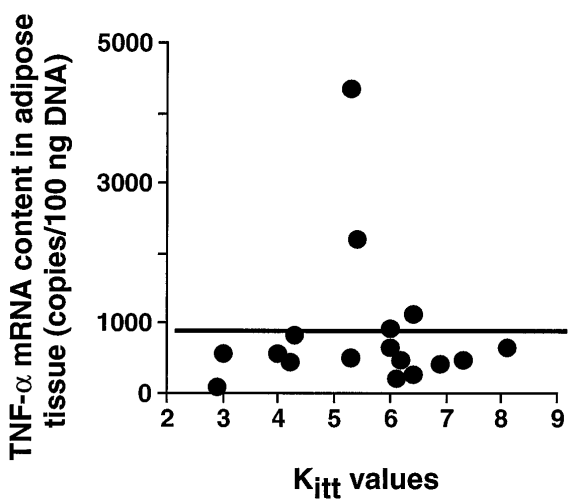

Fig. 5. Correlation between TNF- $\alpha$ mRNA content in adipose tissue of non-obese, non-diabetic subjects and in vivo insulin sensitivity, as indicated by $\mathrm{K}_{\mathrm{itt}}$ values

mRNA abundance and either $K_{\text {itt }}$ values $(r=0.0$, $p=0.9)$ (Fig. 5), and insulin $(r=0.4, p=0.14)$ and glucose plasma levels $(r=0.1, p=0.7) 120$ min during OGTT. Furthermore, no significant difference was observed between TNF- $\alpha$ gene expression in adipose tissue from relatively insulin-sensitive subjects $\left(n=9, K_{\text {itt }}\right.$ values greater than 6) and relatively insulin-resistant subjects $\left(n=8, K_{\text {itt }}\right.$ values less than 6$)$ (data not shown).

Insulin receptor content and relationship to insulin sensitivity. The insulin receptor content in adipose tissue samples was measured by ELISA and ranged from 6.5 to $35.2 \mathrm{ng} / \mathrm{mg}$ protein with a median value of 21.5 and a mean value \pm SEM of $21.6 \pm 1.8$. No significant correlation was observed between insulin receptor content and either $\mathrm{K}_{\mathrm{itt}}$ values or plasma glucose and insulin levels. Also no difference was observed in the insulin receptor content between adipose tissue of relatively insulin-sensitive subjects $\left(n=9, K_{i t t}\right.$ values greater than 6$)$ and from relatively insulin-resistant subjects $\left(\mathrm{n}=10, \mathrm{~K}_{\mathrm{itt}}\right.$ values less than 6) (data not shown). 


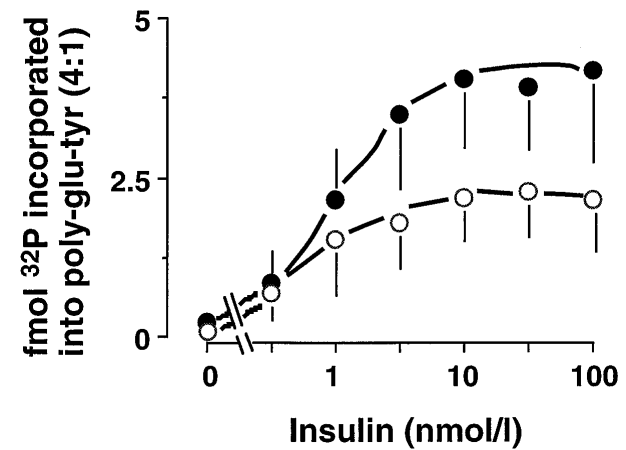

Fig. 6. Insulin stimulation of insulin receptor tyrosine-kinase activity from adipose tissue of 4 relatively insulin-sensitive subjects $\left(\bullet, K_{\text {itt }}\right.$ value higher than 6$)$ and 4 relatively insulin-resistant subjects $\left(O, \mathrm{~K}_{\mathrm{itt}}\right.$ values lower than 6$)$. Data are expressed as mean $\pm \mathrm{SEM}$

Insulin receptor tyrosine-kinase activity and relationship to insulin sensitivity. In eight subjects, four relatively insulin-sensitive $\left(\mathrm{K}_{\mathrm{itt}}\right.$ values greater than 6$)$ and four relatively insulin-resistant $\left(\mathrm{K}_{\mathrm{itt}}\right.$ values less than 6), sufficient adipose tissue was available to measure insulin receptor tyrosine-kinase activity. As we have previously observed [27, 45], at all insulin concentrations, insulin-stimulated receptor tyrosinekinase activity in adipose tissue from insulin-resistant subjects was significantly ( $p=0.017$, by two-way ANOVA test) lower that that observed in adipose tissue from insulin-sensitive subjects (Fig. 6). However, probably due to the small number of subjects studied for insulin receptor tyrosine-kinase activity, no significant correlation was observed between this receptor function and either $\mathrm{K}_{\mathrm{itt}}$ values or PC-1 content.

\section{Discussion}

The exact mechanism(s) that cause decreased insulin receptor tyrosine-kinase activity in insulin-resistant subjects, are unknown. Since mutations of the insulin receptor molecule are very uncommon [47, 48], reduced insulin receptor activation in the vast majority of these subjects is most likely induced by factors that modulate insulin receptor function. These factors may include membrane glycoprotein PC-1 [21] and cytokine TNF- $\alpha$ [22]. Most previous studies concerning these insulin receptor inhibitors in human insulin resistance have employed obese and/or NIDDM patients [21, 26, 32-34]; it is possible, therefore, that in those studies the results obtained were a consequence (at least in part) of either the metabolic or the hormonal factors associated with these states. To avoid these variables, in the present study we investigated subjects who were neither obese nor diabetic. In these subjects we observed that increased adipose tissue PC-1 content was associated with both in vivo whole body insulin resistance and in vitro reduced insulin stimulation of insulin receptor tyrosine-kinase activity. We recently reported similar data in skeletal muscle of non-obese, non-diabetic subjects [27]. Taken together these data demonstrate, therefore, that increased PC-1 content in insulin target tissues is associated with reduced insulin sensitivity when neither obesity nor NIDDM are present.

The molecular mechanisms by which PC- 1 may negatively affect insulin signalling are unknown. PC1 is a class II (cytoplasmic amino terminus) membrane glycoprotein, and is the same protein as liver nucleotide pyrophosphatase/alkaline phosphodiesterase I $[49,50]$. PC- 1 is also related to autotaxin and gp 130 RB13-6 [51]. In addition to muscle and adipose tissue, $\mathrm{PC}-1$ is expressed in the plasma membranes and intracellular membranes of plasma cells, placenta, the distal convoluted tubule of the kidney, ducts of the salivary gland, epididymis, proximal part of the vas deferens, chondrocytes and dermal fibroblasts [52]. PC-1 extracellular domain has enzymatic activity that hydrolyses phosphosulphate, pyrophosphate and phosphodiesterase bonds. We have recently shown, however, that elimination of this enzymatic activity by mutagenesis does not interfere with the ability of PC-1 to inhibit insulin receptor tyrosine-kinase activity [53]. In addition, we have evidence, by both immunopurification and cross-linking studies, that PC-1 may directly associate with the insulin receptor (B. Maddux, I.D. Goldfine, unpublished observation). We believe, therefore, that one possible mechanism by which PC- 1 inhibits the insulin receptor tyrosine-kinase activity is by physical association of the two molecules.

In contrast to PC-1, no relationship between TNF$\alpha$ expression and insulin sensitivity was found, either in vivo or in vitro. These observations suggest, therefore, that adipose tissue TNF- $\alpha$ does not play a role in human insulin resistance when neither obesity nor NIDDM are present. These data are agree with previous studies suggesting that TNF- $\alpha$ overexpression plays a major role in the pathophysiology of obesityassociated human insulin resistance [32-34, 54]. However, since we have not measured TNF- $\alpha$ protein levels, our data should be interpreted with caution.

Finally, confirming previous observations [19] we found no relationship between insulin receptor content in adipose tissue and whole body insulin sensitivity.

As a general comment, it should be pointed out that in our study (as well as in all studies dealing with tissue biopsies) surgery and anaesthesia may have affected the parameters measured. However, the interference(s), if any, is likely to be similar in all subjects studied, not altering, therefore, the observed linear relationship between insulin sensitivity and PC-1 content.

It is likely that insulin resistance is a multifactorial process involving both genetic and acquired 
components [1-2]. The present study in adipose tissue and our previous study in muscle tissue [27] demonstrate that, in non-obese, non-diabetic subjects, elevated membrane glycoprotein PC-1 content in insulin target tissues is associated with reduced insulin sensitivity, both in vivo and in vitro. These observations raise the possibility, therefore, that $\mathrm{PC}-1$ may play a primary or early role in the pathophysiology of human insulin resistance.

A cknowledgements. L.F. is the recipient of a Juvenile Diabetes Foundation post-doctoral fellowship; J.F. Y. was supported by NHRSA DK07418.

\section{References}

1. Reaven G (1988) Role of insulin resistance in human disease. Diabetes 37: 1595-1607

2. DeFronzo RA, Bonadonna RC, Ferrannini E (1992) Pathogenesis of NIDDM. A balanced overview. Diabetes Care 15: $318-368$

3. Bogardus C (1993) Insulin resistance in the pathogenesis of NIDDM in Pima Indians. Diabetes Care 16 [Suppl 1]: 228231

4. Taylor SI (1994) Insulin resistance or insulin deficiency: which is the primary cause of NIDDM? Diabetes 43: 735740

5. Beck-Nielsen H, Groop LC (1994) Metabolic and genetic characterization of prediabetic states. J Clin Invest 94: 1714-1721

6. Kahn RC (1994) Insulin action, diabetogenes, and the cause of type II diabetes. Diabetes 43: 1066-1084

7. Olefsky JM, Nolan JJ (1995) Insulin resistance and non-insulin-dependent diabetes mellitus: cellular and molecular mechanisms. Am J Clin Nutr 61 [Suppl]: 980S-986S

8. Haring HU (1991) The insulin receptor: signalling mechanism and contribution to the pathogenesis of insulin resistance. Diabetologia 34: 848-861

9. Caro JF, Sinha MK, Raju SM et al. (1987) Insulin receptor kinase in human skeletal muscle from obese subjects with and without noninsulin dependent diabetes. J Clin Invest 79: $1330-1337$

10. Arner P, Pollare T, Lithell H, Livingstone JN (1987) Defective insulin receptor tyrosine-kinase in human skeletal muscle in obesity and type 2 (non-insulin-dependent) diabetes mellitus. Diabetologia 30: 437-440

11. Obermaier-Kusser B, White MF, Pongratz DE et al. (1989) A defective intramolecular autoactivation cascade may cause the reduced kinase activity of the skeletal muscle insulin receptor from patients with non-insulin-dependent diabetes mellitus. J Biol Chem 264: 9497-9504

12. Maegawa H, Shigeta Y, Egawa K, Kobayashi M (1991) Impaired autophosphorylation of insulin receptors from abdominal skeletal muscle in non-obese subjects with NIDDM. Diabetes 40: 815-819

13. Nyomba BL, Ossowski VM, Bogardus C, Mott DM (1990) Insulin-sensitive tyrosine-kinase: relationship with in vivo insulin action in humans. Am J Physiol 258: (Endocrinol Metab 21): E964-E974

14. Nolan JJ, Freidenberg G, Henry R, Reichart D, Olefsky JM (1994) Role of human skeletal muscle receptor kinase in the in vivo insulin resistance of noninsulin-dependent diabetes mellitus and obesity. J Clin Endocrinol Metab 78: 471-477
15. Klein HH, Vestegaard H, Kotzke G, Pedersen O (1995) Elevation of serum insulin concentration during euglycemic hyperinsulinemic clamp studies leads to similar activation of insulin receptor kinase in skeletal muscle of subjects with and without NIDDM. Diabetes 44: 1310-1317

16. Freidenberger GR, Henry RR, Klein HH, Reichart DR, Olefsky JM (1987) Decreased kinase activity of insulin receptors from adipocytes of non-insulin-dependent diabetic subjects. J Clin Invest 79: 240-250

17. Sihna MK, Pories WJ, Flickinger EG, Meelheim D, Caro JF (1987) Insulin-receptor kinase activity of adipose tissue from morbidly obese humans with and without NIDDM. Diabetes 36: 620-625

18. Takayama S, Kahn CR, Kubo K, Foley JE (1988) Alterations in insulin receptor autophosphorylation in insulin resistance: correlation with altered sensitivity to glucose transport and antilipolysis to insulin. J Clin Endocrinol Metab 66: 992-997

19. Grasso G, Frittitta L, Anello M, Russo P, Sesti G, Trischitta $\mathrm{V}$ (1995) Insulin receptor tyrosine-kinase activity is altered in both muscle and adipose tissue from non-obese normoglycaemic insulin resistant subjects. Diabetologia 38: 55-61

20. Handberg A, Vaag A, Vincent J, Beck-Nielsen H (1993) Decreased tyrosine kinase activity in partially purified insulin receptor from skeletal muscle of young, non-obese first degree relatives of patients with type 2 (non-insulindependent) diabetes mellitus. Diabetologia 36: 668-674

21. Maddux BA, Sbraccia P, Kumakura S et al. (1995) Membrane glycoprotein PC-1 and insulin resistance in non-insulin-dependent diabetes mellitus. Nature 373: 448-451

22. Hotamisligil GS, Spiegelman BM (1994) Tumor necrosis factor- $\alpha$ : a key component of the obesity-diabetes link. Diabetes 43: 1271-1278

23. Ahmad F, Considine RV, Goldstein BJ (1995) Increased abundance of the receptor-type protein-tyrosine phosphatase LAR accounts for the elevated insulin receptor dephosphorylating activity in adipose tissue of obese human subjects. J Clin Invest 95: 2806-2812

24. Considine RV, Nyce MR, Allen LE et al. (1995) Protein kinase $\mathrm{C}$ is increased in the liver of humans and rats with non-insulin-dependent diabetes mellitus: an alteration not due to hyperglycaemia. J Clin Invest 95: 2938-2944

25. Whitehead JP, Humphreys PJ, Maasen JA, Poller DE, Krok A, O'Rahilly S (1995) Increased PC-1 phosphodiesterase activity in patients with post-receptor insulin resistance but not in patients with insulin receptor mutations. Diabetologia 38 [Suppl 1]: 65A (Abstract)

26. Youngren JF, Maddux BA, Sasson S et al. (1996) Skeletal muscle content of membrane glycoprotein PC-1 in obesity: relationship to muscle glucose transport. Diabetes (in press)

27. Frittitta L, Youngren J, Vigneri R, Maddux BA, Trischitta $\mathrm{V}$, Goldfine ID (1996) PC-1 content in skeletal muscle of non-obese, non-diabetic subjects: relationship to insulin receptor tyrosine-kinase and whole body insulin sensitivity. Diabetologia 39: 1190-1195

28. Marin P, Rebuffé-Scrive M, Smith U, Bjorntorp P (1993) Glucose uptake in human tissue. Metabolism 36: 11541160

29. Reaven GM (1995) The fourth musketeer - from Alexandre Dumas to Claude Bernard. Diabetologia 38: 3-13

30. Rebrin K, Steil GM, Getty L, Bergman RN (1995) Free fatty acid as a link in the regulation of hepatic glucose output by peripheral insulin. Diabetes 44: 1038-1045

31. Hotamisligil GS, Budavari A, Murray D, Spiegelman BM (1994) Reduced tyrosine kinase activity of the insulin receptor in obesity-diabetes. Central role of tumor necrosis factor- $\alpha$. J Clin Invest 94: 1543-1549 
32. Kern PA, Saghizadeh M, Ong JM, Bosch RJ, Deem R, Simsolo RB (1995) The expression of tumor necrosis factor in human adipose tissue. Regulation by obesity, weight loss, and relationship to lipoprotein lipase. J Clin Invest 95: 2111-2119

33. Hotamisligil GS, Arner P, Caro JF, Atkinson RL, Spiegelman BM (1995) Increased adipose tissue expression of tumor necrosis factor- $\alpha$ in human obesity and insulin resistance. J Clin Invest 95: 2409-2415

34. Saghizadeh M, Ong JM, Garvey WT, Henry RR, Kern PA (1996) The expression of TNF- $\alpha$ by human muscle. Relationship to insulin resistance. J Clin Invest 97: 1111-1116

35. Bonora E, Moghetti P, Zancanaro C et al. (1989) Estimates of in vivo insulin action in man: comparison of insulin tolerance test with euglycemic and hyperglycemic glucose clamp studies. J Clin Endocrinol Metab 68: 374-378

36. Bradford MM (1976) A rapid and sensitive method for the quantification of microgram quantities of protein utilizing the principle of protein-dye binding. Anal Biochem 72: 248-254

37. Boge A, Roth RA (1991) A nonradioactive assay for the insulin receptor tyrosine-kinase: use in monitoring receptor tyrosine-kinase activity after activation of overexpressed protein kinase $\mathrm{C} \alpha$ and high glucose treatment. J Immunol Methods 140: 191-196

38. Horie K, Yano T, Funakoshi I, Yamashina I (1988) Elevated nucleotide pyrophosphatase activity in cultured skin fibroblasts from patients with Lowe's syndrome. Clin Chim Acta 177: 41-48

39. Wang AM, Doyle MV, Mark DF (1989) Quantitation of mRNA by the polymerase chain reaction. Proc Natl Acad Sci USA 86: 9717-9721

40. Sibert PD, Larrick JW (1992) Competitive PCR. Nature, 359: 557-558

41. Bouaboula M, Legoux P, Passegue B et al. (1992) Standardization of mRNA titration using a polymerase chain reaction involving co-amplification with a multispecific internal control. J Biol Chem 267: 21830-21838

42. Pennica D, Nedwin GE, Hayflick JS et al. (1984) Human tumor necrosis factors: precursor structure, expression and homology to lymphotoxin. Nature 312: 724-729

43. Nedwin GE, Naylor SL, Sakaguchi AY et al. (1985) Human lymphotoxin and tumor necrosis factor genes: structure, homology and chromosomal localization. Nucleic Acids Res 13: 6361-6373

44. Frittitta L, Grasso G, Munguira E, Vigneri R, Trischitta V (1993) Insulin receptor tyrosine-kinase activity is reduced in monocyte from non-obese normoglycaemic insulin resistant subjects. Diabetologia 36: 1163-1167

45. Steele-Perkins G, Roth RA (1990) Insulin-mimetic anti-insulin receptor monoclonal antibodies stimulate receptor kinase activity in intact cells. J Biol Chem 265: 9458-9463

46. Frittitta L, Grasso G, Vigneri R, Trischitta V (1995) A reduced Glut 4 content in adipose tissue is not an early defect in the development of human insulin resistance. Diab Nutr Metab 8: 262-266

47. Taylor SI, Cama A, Accili D et al. (1992) Mutations in the insulin receptor gene. Endocr Rev 13: 566-595

48. Moller DE, Yokota A, Flier JS (1989) Normal insulin-receptor cDNA sequence in Pima Indians with NIDDM. Diabetes 38: 1496-1500

49. Rebbe NF, Tong BD, Hickman S (1993) Expression of nucleotide pyrophosphatase I activities of PC-1, the murine plasma cell antigen. Mol Immunol 30: 87-93

50. Belli SI, Goding JW (1994) Biochemical characterization of human PC-1, an enzyme possessing alkaline phosphodiesterase I and nucleotide pyrophosphatase activities. Eur J Biochem 226: 433-434

51. Murata JM, Lee HY, Clair Tet al. (1994) cDNA Cloning of the human tumor motility-stimulating protein, autotaxin, reveals a homology with phosphodiesterase. J Biol Chem 269: 30479-30485

52. Harap AR, Goding JW (1988) Distribution of the murine plasma cell antigen PC-1 in non-lymphoid tissues. J Immunol 141: 2317-2320

53. Grupe A, Alleman J, Goldfine ID, Sadick M, Stewart TA (1995) Inhibition of insulin receptor phosphorylation by PC-1 is not mediated by the hydrolysis of adenosine triphosphate or the generation of adenosine. J Biol Chem 270: 22085-22088

54. Hotamisligil GS, Peraldi P, Budavari A, Ellis R, White MF, Spiegelman BM (1996) IRS-1-mediated inhibition of insulin receptor tyrosine-kinase activity in TNF- $\alpha$ - and obesity-induced insulin resistance. Science 271: 665-668 